\title{
The Early Cretaceous in situ shallow-marine carbonates containing typical Tethyan biota in the Ishido Formation, Kanto Mountains, central Japan
}

\author{
Yaushiro Iba* and Ken-ichi Hirauchi** \\ Received October 20, 2008 Accepted December 10, 2008 \\ * Department of Earth and Planetary Science, University of Tokyo, Tokyo 113-0033, Japan \\ ** Department of Earth and Planetary Systems Science, Hiroshima University, Hiroshima 739-8526, Japan \\ Corresponding author; Y. Iba, iba@eps.s.u-tokyo.ac.jp
}

The distribution of carbonate platforms and associated biota is considered to be an essential indicator of the tropical marine environment and biotic realm (Tethyan Realm) in the Cretaceous. Understanding shallow-marine carbonates and associated biota in the Northwest Pacific provides important clues for evaluating the paleobiogeographic and paleoenvironmental history in this region (Iba and Sano, 2007, 2008). However, the detailed lithology and paleontology of shallow-marine carbonates from the pre-Aptian Cretaceous of Northwest Pacific are still poorly understood (Iba and Sano, 2007).

The Sanchu Cretaceous System is widely distributed along the axial part of the Chichibu Belt in the western Kanto Mountains (Fig. 1), and is referable to the Lower Cretaceous fore-arc basin fill sediments underlain unconformably by the Jurassic Accretionary wedge. We report a pre-Aptian Cretaceous (late Hauterivian-Barremian) small-scale in situ shallow-marine carbonates and calcareous sandstone (total thickness is about $5.5 \mathrm{~m}$ with poor lateral continuity) in the lowermost part of the Ishido Formation of the Sanchu Cretaceous System exposed along the Otchi Creek, Gunma Prefecture, central Japan (Figs. 1, 2, and 3). These calcareous sediments lie above basal conglomerate belonging to the Ishido Formation (Figs. 3, 4), and contain abundant Mesogean taxa (e.g., hermatypic corals and orbitolinid foraminifers), "Tethyan non-rudist bivalves" (Neithea atava and Rastellum sp.), and coated grains (Figs. 4,5). These shallow-marine carbonates are characterized by 1) their small scale, typically several meters both in thickness and lateral continuity, and 2) being intercalated with siliciclastic sequences and containing abundant terrigenous clastics. These features illustrate one of the typical mode of occurrence of shallow-marine carbonates and the Tethyan biota in island arc and/or active-margin settings (Iba and Sano, 2007). The presence of shallow-marine carbonates and associated biota in the Ishido Formation, clearly indicates that this region belonged to the Tethyan Realm, and was subject to tropical climatic conditions at that time.

\section{References}

Hisada, K., Arai, S. and Miyata, T., 1987, Distribution of serpentinite bodies and its tectonic significance in the southern marginal part of the Sanchu Graben, Kanto Mountains, central Japan. Mem. Osaka Kyoiku Univ., Ser. III, 36, 129-134 (in Japanese with English Abstract).

Iba, Y. and Sano, S., 2007, Mid-Cretaceous step-wise demise of the carbonate platform biota in the Northwest Pacific and establishment of the North Pacific biotic province. Palaeogeo. Palaeoclimatol. Palaeoecol., 245, 462-482.

Iba, Y. and Sano, S., 2008, Paleobiogeography of the pectinid bivalve Neithea, and its pattern of step-wise demise in the Albian Northwest Pacific. Palaeogeo. Palaeoclimatol. Palaeoecol. 267., 138-146.
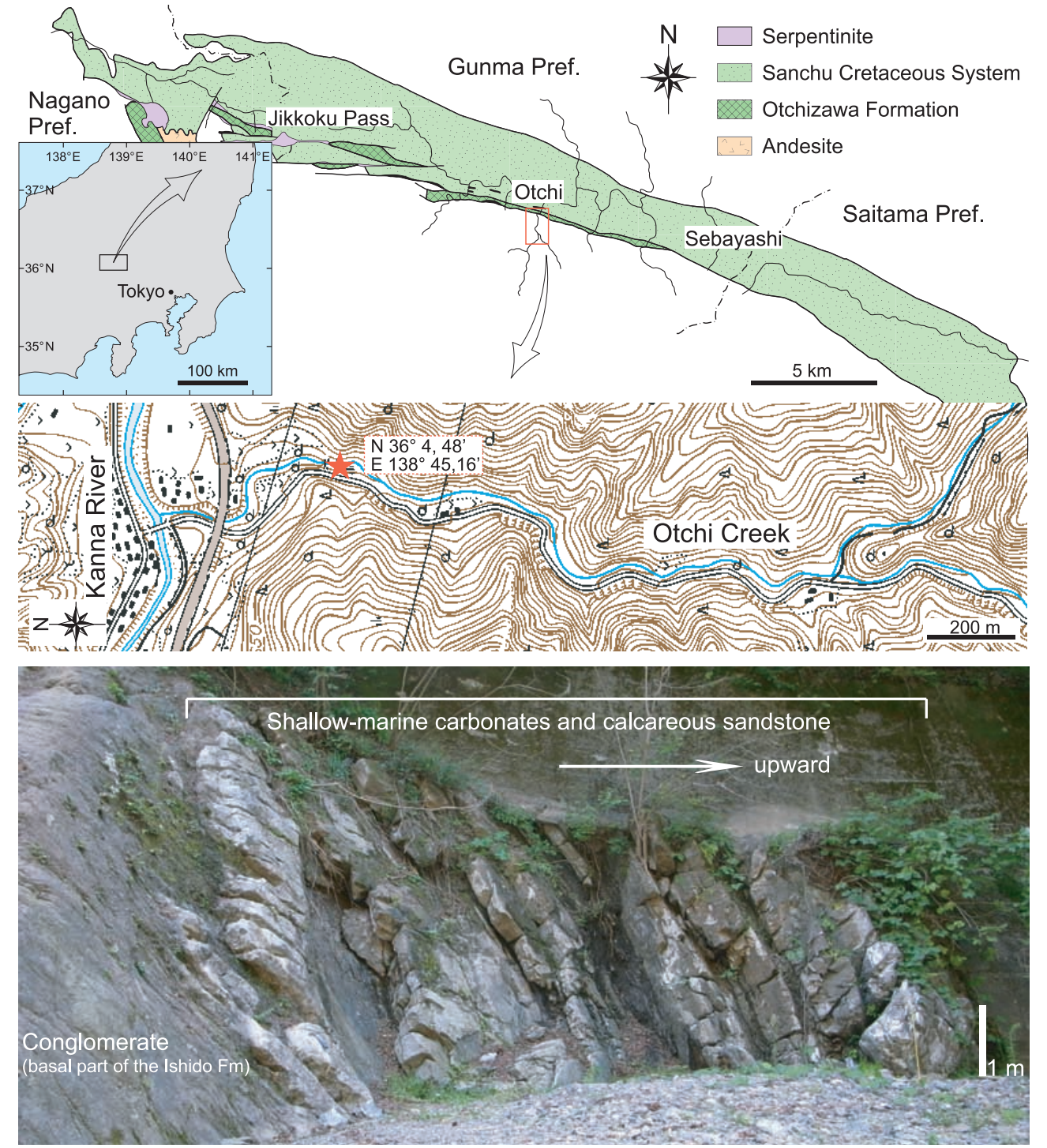

Fig. 1. Locality map. A star indicates the studied outcrop. Geological map modified from Hisada et al. (1987). Topographic map is from the "Ryokamisan" map, scale 1:25000, Geographical Survey Institute of Japan.

Fig. 2. Studied outcrop of shallow-marine carbonates and calcareous sandstone of the lowermost part of the Ishido Formation. 


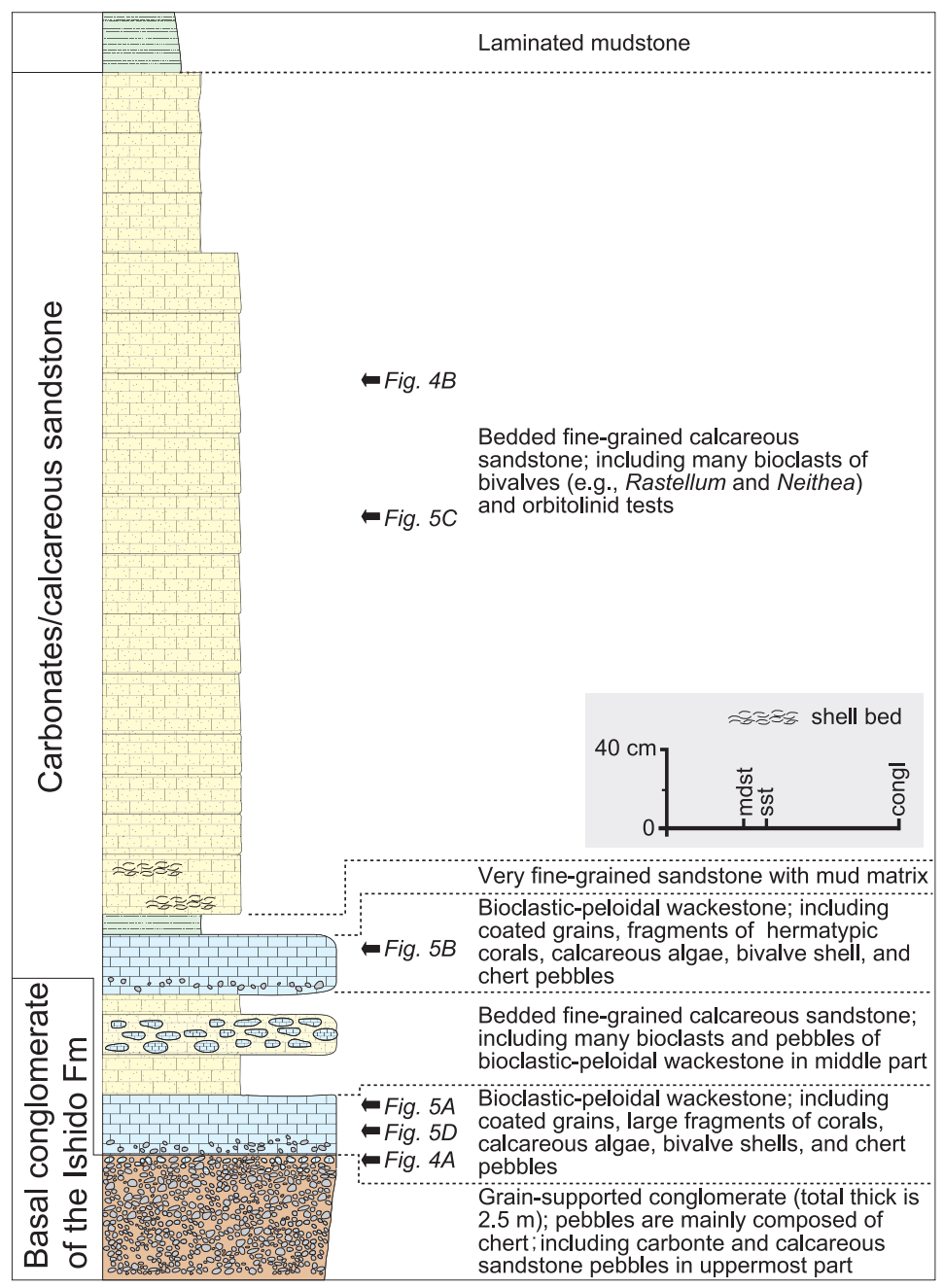

Fig. 3. Columnar section of the shallow-marine carbonates and calcareous sandstone of the lowermost of the Ishido Formation. These calcareous sediments lie above the basal conglomerate of the Ishido Formation and are overlain by dark gray-colored laminated mudstone.
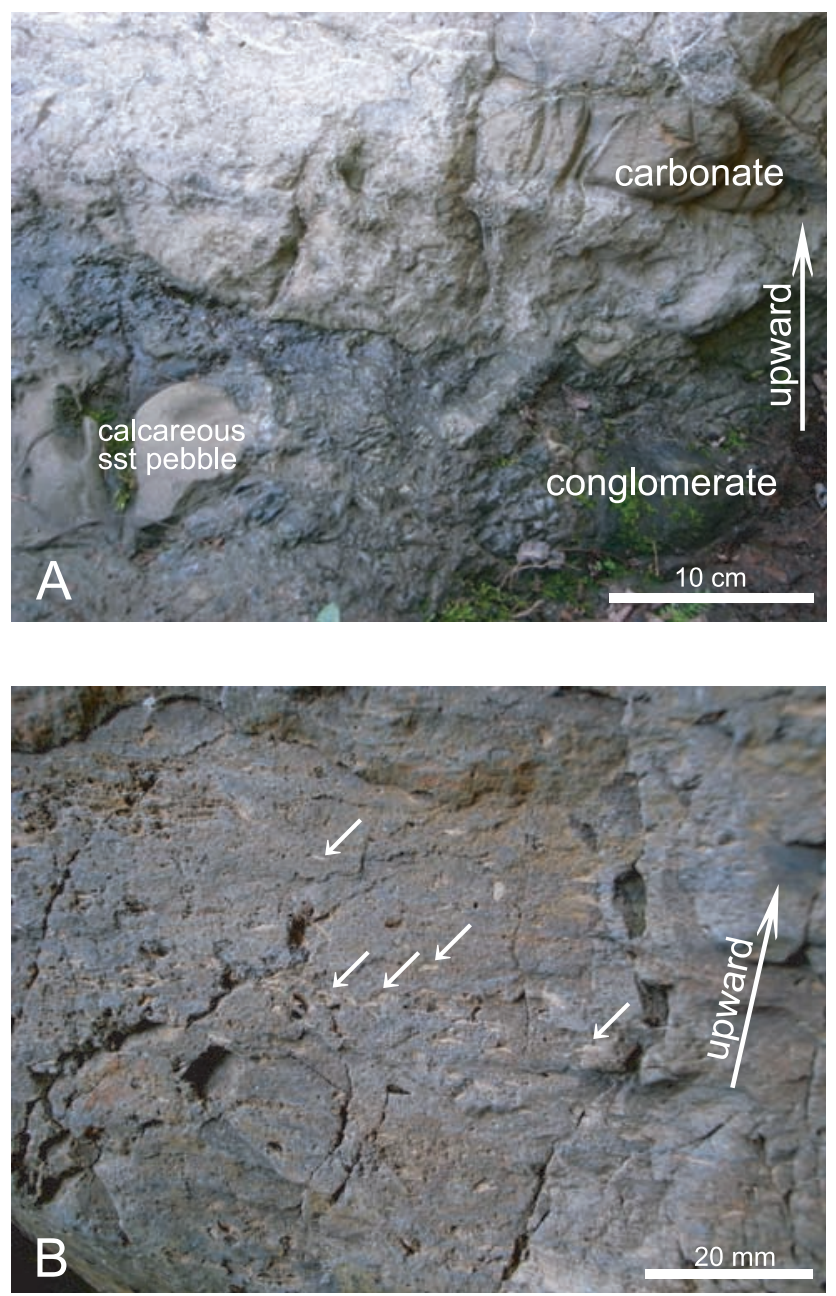

Fig. 4. Photographs of outcrop. A, Boundary between basal conglomerate of the Ishido Formation and carbonate (bioclastic-peloidal wackestone). B, Calcareous sandstone including many orbitolinid tests (indicated by arrows).
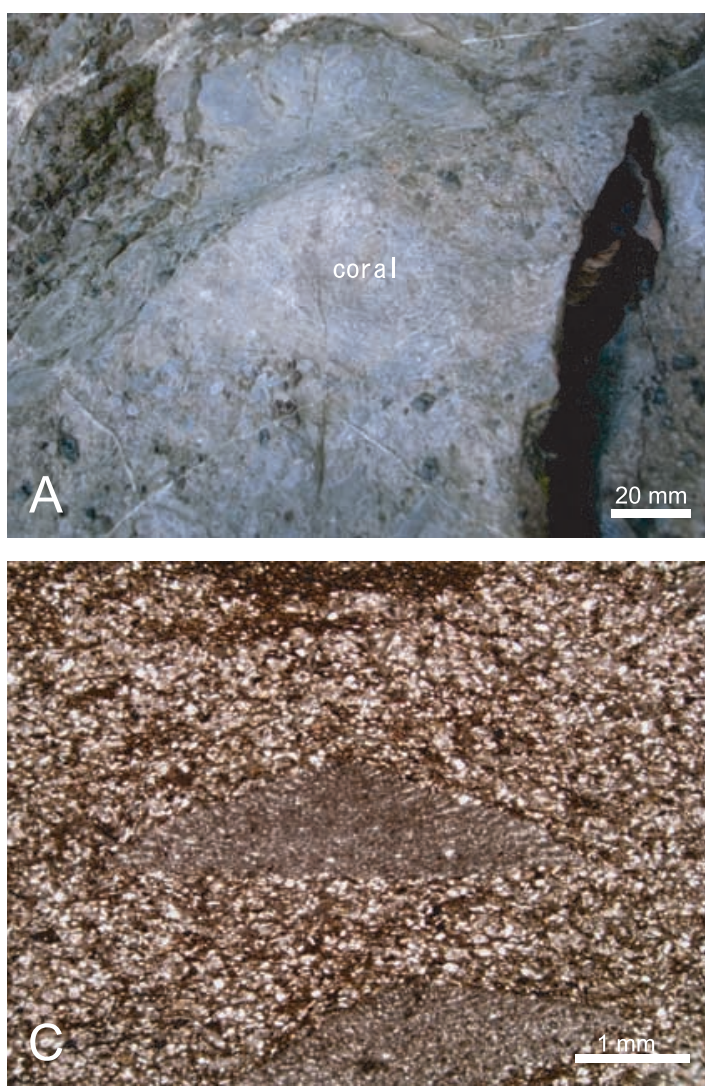

Fig. 5. Mode of occurrence of Tethyan fossils and coated grains. A, Hermatypic coral Transported fragments of hermatypic corals are abundant in this horizon (see Fig. 3). Carbonates contain abundant chert pebbles. B, Rastellum sp. Bivalves occur as both articulated and unarticulated valves. C, Orbitolinid foraminifer in the calcareous sandstone. D, Ooid and intraclast in the bioclasticpeloidal wackestone. 